\title{
ФОРМУЛА „ИСКАЗАНИ ГОВОР : УНУТРАШЬИ ГОВОР” И ДЕФИНИЦИЈЕ НЕПОТПУНИХ РЕЧЕНИЦА У ТРАДИЦИОНАЛНОЈ ГРАМАТИЦИ
}

\begin{abstract}
Рад доноси резултате ауторовог истраживања репрезентативне за другу половину 20. века граматике српског језика у њеном синтаксичком сегменту са дефиницијама и анализом непотпуне реченице. Постављени циљ истраживања је констатовање постојања у тој (типичној за то време) граматици когнитивних елемената чији је центар формула говор исказани : говор унутрашњи, која је предмет расправљања у текстлингвистици. Спекулативним методом који полази од актуелних теоријских расправа (више других истраживача), аутор закључује да су формуле овога типа у тој граматици имплицирана категорија. Она је, по аутору овога рада, најчешће, базирана на интуицији и спонтаним асоцијацијама везаним за учења А. Белића о вези значења и језичких јединица из свих нивоа језика у комуникацији. Овако постављеним истраживањем прагматике, индуктивним закључивањем, по аутору, анализа би могла резултирати и уопштавањима теоријског карактера.

Кључне речи: говор исказани/унутрашњи, традиционална граматика, инструментаријум, непотпуне реченице, психо-/когнитивна/социо-/текст-/лингвистика, Стевановић, Чомски, Радовановић, Виготски, Вајли, Терон.
\end{abstract}

Као предмет научних испитивања чији би резултати имали рефлекс у граматикама, у наслову дата опозиција говор исказани : говор унутрашьи ${ }^{1}$ - није забележена у опису и оценама наших граматика. Уосталом - као што није поменута ни у анализама и де фин ицијама одређених синтаксичких категорија које налазимо у нашим традиционалним граматикама. У приказима ове или оне граматике то има оправдања: на пример, рећи нешто као „у тој конкретној граматици та се формула е к с п л и ц и т н о не налази, зато што је за сада у оквирима теоријског истраживања”.

\footnotetext{
*slstanojcic@gmail.com

${ }^{1}$ Сасвим прецизан садржај формуле овде би био говор исказани/написани : говор унутрашњи; у енглеским преводима Виготског overt speech : inner speech (Виготски 1962), код неких каснијих аутора, говорника енглеског језика - outer speech : inner speech (Вајли 2006).
} 
Из овога би се могао извести и захтев да таква констатација свакако треба да буде у аналитичком делу приказа - бар као утврђивање чињенице да те формуле нема у (тој и тој) граматици, уз препоруку (будућим ауторима граматика) да она треба да буде у анализи и дефиницијама. Јер - и међу нашим општелингвистичким дисциплинама, у другој половини 20. века, пре свега у београдској лингвистичкој школи, ${ }^{2}$ у радовима В. Половине налазимо - не само теоријско тумачење ове материје него и прагматична упутства намењена аналитичкој страни текстлингвистике (Ристић 2000: 9-19).

Констатујући овакво стање ствари, ипак не можемо рећи да ни у граматикама тзв. традиционалног приступа нема дефиниција синтаксичких јединица са категоријом дихотомије говор исказани : говор унутрашњи. Има је - али само као имплициране у ьима.То имплицирање је у њима, најчешће, и н т у и т и в н о и спонтаним а с о ц и ј а ц и ј а м а везано за учења представника Прашке школе у нашој науци о језику - А. Белића о вези значењ и језичких јединица свих нивоа језика у комуникацији (Белић 1998). А то и зато што се нашим традиционалним граматикама не може негирати дефинисање синтаксичких јединица првенствено уз узимање у обзир семантике, што подразумева и аналитичке инструментарије и психолингвистике и когнитивне лингвистике. Оне све као идејну основу, бар у нашој лингвистици, имају Белићева учења о односу језика и мишљења. Зато и њихове анализе и дефиниције садрже увек позивање на значење, на семантичку страну односа дискурсних јединица у једном целовитом комплексу тих јединица. Тиме - кад је реч о говорниковој/саговорниковој перцепцији језичког знака - текст дате граматике постаје поље које и когнитивна лингвистика истражује.

2. Овај рад није студија с циљем да донесе резултате (критичког) испитивања анализе и дефиниција у више граматика (ако не и у свима датога периода), на пример, у другој половини 20. века, и да утврди у њима присуство тумачења грађе са позиције семантичко-когнитивне анализе. Само делимично овај рад има тај циљ: у делу у којем налази реализацију формуле говор исказани : говор унутрашњи и д е ф и н и ш е њене појавне знаке. Дакле, ограничава се на указивање да се и у дефиницијама и класификовању текста и таквих граматика (довољно репрезентативних за другу половину 20. века) налазе исти елементи анализе које налазимо у д и с курс ан а л изи/текс т л и н г в и с т и ц и ${ }^{3}$. Само су ти елементи формулисани другом, ,традиционалном", терминологијом.

Зато је у овом раду анализа вршена на одговарајућем тексту (поглављу) изабране граматике. На тексту у којем има (или нема) - што је и природно - дефиниција те језичке материје у домену синтаксичких категорија, и то дефиниција које показују да конкретни граматичар запажа (макар и интуитивно) дихотомију коју смо изразили формулом говор исказани : говор унутрашњи. Али - тај текст је овде само материјал на којем се указује на

\footnotetext{
${ }^{2}$ Види и у Новом Саду, код Св. Савић и сарадника.

${ }^{3}$ А у њој су највише заступљени методи и когнитивне/семантичке лингвистике, уз (доминантне) социолингвистичке и психолингвистичке методе.
} 
начине примене м одел а ан а л и зе које налазимо у теоријским делима чији је предмет однос језика и мишљења.

Прецизно речено, само с тим делом циља, рад је концентрисан на налажење и идентификовање (у датом сегменту једне граматике) елемената који показују знаке (бар) ин ту ит ивног / асоцијативн о г ${ }^{4}$ граматичаревог ослањања и на оне анализе које су изграђене на инструментарију дефинисаном терминима когнитивне/семантичке лингвистике. А један од основних њених инструмената свакако је и увођење у анализу појма дихотомије говор исказани : говор унутрашњи.

Ако се (или када се) идентификује горе описани текст, полазна тачка овога рада је аксиоматска претпоставка да је наш традиционални граматичар, анализирајући и дефинишући синтаксичке јединице одређене класе, полазио од одавно усвојених приступа језику који су засновани (код нас бар) на белићевским дефиницијама односа језика и мишљења. Па и на Белићевом појму (термину) језичко осећање. „Овакво издвајање општих делова врши наше језичко осећање... И оно је - апсолутно” (Белић 2000: 527). Када се стави у појмове анализе постаје и део текстлингвистичког инструментарија и може се применити у језичкој анализи свих нивоа језика.

3. Заправо, идеју о могућности повезивања двају инструментарија анализе - традиционалног и „новог” текстлингвистичког, дао нам је Норберт Вајли (Norbert Wiley) својом расправом Inner Speech as a Language: A Saussurean Inquiry. ${ }^{5}$ Пошто је навео (у историјској перспективи) више имена „who regarded thought as inner speech” - од античких и средњовековних мислилаца до модерне епохе (Платон и софисти, Св. Августин, Чомски, Фодор, Арчер и др.), Вајли истиче да ће се он ограничити, у овој прилици, на „Тhe analisys of inner speech, attempt to approach it in linguistic manner", па завршава једноставном констатацијом: „Inner speech is a streamlined version of outer speech, characterized by short cuts and speaker peculiarities" (Вајли 2006: 319-320). Притом, спомињући и анализе Виготског, ${ }^{6}$ зачетника овог типа приступа односу језика и мишљења - он се ослања на Сосира с циљем да сагледа „до које се мере унутрашњи говор може третирати као језик” (Вајли 2006: 320).

\footnotetext{
${ }^{4}$ Оно се заснива на (у нашој лингвистици прихваћеним) теоријским ставовима Белићеве „Београдске лингвистичке школе”, која је сва заснована на дефинисању односа је з и ч ко г 3 на ка и значења.

${ }^{5}$ Journal for the Theory of Social Behaviour Vol. 36, Issue 3, (Edit. By John Wiley), 2006, pp. 319-341, Oxford: Wiley \& Sons Lt. [https://philpapers.org/rec/WILISA]

${ }^{6}$ Ово је полазиште, у познатој његовој књизи, изражено једноставним резимеом резултата његових теоријских и експерименталних истраживања; каже Виготски: ”The content and structure of our research have been varied and complex. Nonetheless, each task we have faced in our work has been subordinated to our general goal and connected to the work that preceded and followed it.... we can summarize the contributions of our research effort in the following way: (1) we have provided experimental evidence indicating that word meaning develops in childhood and identified the basic stages of this process; (2) we have identified the process involved in the development of scientific concepts and demonstrated how this process differs from the development of spontaneous concepts; (3) we have clarified the psychological nature of written speech as a distinct speech function and explored its relationship to thinking; and (4) we have made a contribution to the experimental study of inner speech and the relationship between inner speech and thinking" (Виготски 1934: 39-40).
} 
4. Треба истаћи да овакав процес посматрања у основи налазимо и код наших граматичара традиционалне оријентације. Али - с једном разликом: они полазе од реалних примера (узетих из речника или ексцерпираних из текстова) да би неку морфосинтаксичку категорију граматички одредили и то ослањајући се на значење и асоцијативне везе у једној таквој јединици која се констатује у синтаксичком систему српског језика. И, природно, обрађују је у одговарајућем тексту (поглављу) синтаксе конкретног језика. Тај став сасвим је близак и ставу Н. Чомског При томе, граматичари у XX веку полазне принципе налазе - у савременим им учењима А. Белића о природи везе мишљења (и значења) и језичког знака свих нивоа језика. ${ }^{7}$

Из овога бисмо закључили да је на овоме плану најупадљивији сегмент такве граматике - онај чији су предмет дефинисање и опис појма који је у традиционалној граматици означен терминима: непотпуна реченица, реченица без развијених главних делова, елиптична реченица и сл. Зато бисмо на томе сегменту (= поглављу као делу целине текста, како га дефинише дискурс анализа/текстлингвистика) указали на дефиниције (и анализе) традиционалне граматике које имају имплицирану дату дихотомију, изражену формулом говор исказани : говор унутрашњи.

5. Заправо, Вајли и Чомски се разликују у томе што овај други, уз социјални стимуланс, тј. потребу човекову за комуникацијом и учење језика кроз које пролази дете у својој раној фази развитка - уводи (и ставља на примарно место) елемент човекове урођене способности да поседује у својој свести „универзалну граматику (,universal grammar”), која ће обезбедити његово будуће прихватање граматичког знања" (Чомски 2006: 76-77). ${ }^{8}$

Да бисмо ове дефиниције што више приближили нашем уверењу о постојању - у изабраној традиционалној граматици - имплицитног ослањања на значењску везу језичког исказа са контекстом (па и ванјезичким чиниоцима у формирању дискурса), навешћемо следеће Вајлијево дефинисање таквог исказа, ослоњено на Виготског:

„Ванјезичка ситуација такође може надокнадити реченичне делове... [...] Ако сте гладни, размишљате о сусрету са супругом крајем радног дана, планирате свој пут кући, или размишљате о кувању, моћи ћете да изградите слику ваше омиљене радње. Чак у њој и секторе са производима, и тезгу с месом. Ако ова визуелна слика (или перцепција чулом мириса) уђе у вашу главу, ви већ имате стимуланс који може функционисати на синтаксич-

\footnotetext{
${ }^{7}$ По учењу нашег лингвисте Александра Белића, одређен број таквих потенцијала, заправо, је - константа свих језика (Белић 1998: 361-364), или језичка универзалија у терминологији западних лингвистика.

${ }^{8}$ (a) "The study of universal grammar [...] is a study of the nature of human intellectual capacities. It tries to formulate the necessary and sufficient conditions that a system must meet to qualify as a potential human language, conditions that are not accidentally true of the existing human languages, but that are rather rooted in the human "language capacity," and thus constitute the innate organization that determines what counts as linguistic experience and what knowledge of language arises on the basis of this experience [...] In practice, the linguist is always involved in the study of both universal and particular grammar" [...]), да би закључио (b) да је, колико је њему познато, ”... the only substantive proposal to deal with the problem of acquisition of knowledge of language is the rationalist conception [...]" (Чомски 2006: 24).
} 
ки начин. У том случају, можете замислити реченицу од једне речи: „Радња!” и [језички] означити све то."

Тај имплицитни члан био би евентуални управни члан те синтагме, док би реализовани материјализовани (фонетски/графички) облик био - његова допуна или одредба. ${ }^{10}$ Тиме је њен опис ове категорије пошао од описа граматичког (синтаксичког) система и ишао према „материјалној бази” дискурсне јединице - према контекстуалним условима (језичким и ванјезичким) у којима је конкретни дискурс/текст настао.У основи дефиниција и анализа које полазе од морфосинтаксичког система и иду у дубинску структуру синтаксичких јединица, чиме се открива и овај тип реченица - налазе се ови принципи традиционалиста и у нашој литератури. И то баш аутора за које се може рећи да припадају школи структурализма. У овом смислу, поменућемо рад М. Радовановића, посвећен парцелацији реченице објављен у његовој књизи Списи из синтаксе и семантике (Радовановић 1990). Тај рад, у својим дефиницијама и анализама, углавном је концентрисан на граматичке структуре са ослонцем на семантичке елементе. Рад је у многим елементима и наставак приступа традиционалне граматике, засноване на Белићевом учењу о односу језичког знака и значења, без детаљнијег позивања на текстлингвистичке приступе. ${ }^{11}$ Разумљиво - са новијим терминолошким апаратом и (структуралистичким) приступом материји.

6. Показаћемо то на примеру граматичареве карактеризације тзв. елиптичних реченица, изведене из анализе примера таквих синтаксичких (па - интуитивно - и из дискурсних) јединица. ${ }^{12}$ У њој је доминантна идеја коју бисмо формулисали исказом, изведним из граматичаревог описа - „таква реченица је заснована на неисказаној мисли а на њу упућују исказани делови реченице, дакле - лексичке речи (па и облици тих речи) које би означавале садржај мисли неизречени су а они се подразумевају"13. У духу ове логике, сасвим је основано и то што аутор прави границу између реченице без изречених главних делова и непотпуних реченица. Ту границу формулише врло јасно констатацијом да су „реченице без развијених главних делова стварно [...] само оне реченице у којима нема предиката, самог

\footnotetext{
9 "Non-linguistic imagery may also substitute for parts of a sentence... [...] If you are getting hungry, thinking about meeting your spouse at the end of a work day, planning your route home, or thinking about cooking, you might get the imagery of your favorite store. Perhaps even of the produce sections and meat counter. If this visual (and olfactory) imagery enters your head you already have a stimulus that can function syntactically. At this point you can think the simple, one-word sentence: "Shop!" and say the whole thing" (Вајли 2006: 321).

${ }^{10}$ Према дефиницијама управо аутора дате граматике.

${ }^{11}$ На њих је М. Радовановић, са пуном научно заснованом аргументацијом, указао, нпр. у својој књизи Сочиолингвистика, Београд: Београдски издавачко-графички завод [Библиотека ХХ век, 35], 1979.

${ }^{12}$ Скоро је сувишно и рећи - такве дефиниције и такве примере доноси свака традиционална граматика српског језика, као и граматике других језика.

${ }^{13}$ Назив/термин елиптичне реченице - пише граматичар - „... би се и могао можда прихватити за све реченице у којих је неизречено нешто од онога што се садржи у мислима које се њима исказују [подвукао - Сл. Ст.]. А ми све овакве реченице, узимајући с њима заједно и оне што их Маретић, за разлику од осталих, назива крњим, зовемо непотпуним реченицама (Стевановић 1973: 96-97).
} 
предиката, или ни предиката ни субјекта. Али ми, наравно, о овим реченицама (непотпуним - напомена Сл. Ст.) не говоримо као о реченицама са изостављеним тим деловима, већ као о језичким целинама у којима тих делова никад ни било није (подвукао Сл. Ст.) зато што су оне и у облику у коме су употребљене довољне да искажу мисао коју садрже" (Стевановић 1973: 95).

7. Управо директна илустрација нашег мишљења о тако заснованим дефиницијама и анализама јесте сегмент граматике коју овде анализирамо и она је, заправо, граматичарева дефиниција непотпуних реченица, добијена, природно - његовом анализом која је базирана на Белићевом учењу о мишљењу и језичком знаку. Граматичарева дефиниција, коју дајемо у сажетој форми, гласи:

„Реченице без развијених главних делова стварно су само оне реченице у којима нема предиката, самог предиката, или ни предиката ни субјекта. Али ми, наравно, о овим реченицама не говоримо као о реченицама са изостављеним тим деловима, већ као о језичким целинама у којима тих делова никад ни било није, зато што су оне и у облику у коме су употребљене довољне да искажу мисао коју садрже" [...] оне су само по форми непотпуне. јер није изречен и облик њихова предиката, али им по смислу, по садржини, као ни по синтаксичком односу њихових делова, ништа не недостаје” (Стевановић 1973: 95-97).

Ова констатација омогућила је граматичару да прецизира и класификује тај аморфни скуп свих реченица у више врста или типова. Ми ћемо овде низ датих категорија из тога скупа, које се у датој граматици детаљно издвајају дати само у најопштијим цртама наводећи три облика (морфосинтаксичка), са примерима који се наводе у овој граматици. У тој схеми су:

- реченице са изостављеним предикатом: /Нека ради с њима/ како му [*je=Ø...] драго; /Петроније узме пушку,/ na [*oде, кре$н y \ldots=\varnothing \ldots$.$] на Брајиће, које су констатоване и у давним граматика-$ ма; а који тип и дата граматика илуструје примерима из књижевних дела XX века, или из свакодневног језика: ... /врата на клупским собама се отварају./ Их, на мене $\left[{ }^{*} j e=\varnothing\right.$, *дође, *je домао $=\varnothing$...] ред;

- реченице у форми помоћних речи: /И син и унуци ће ме заборавити./ Ако. [*нека ме забораве $=\varnothing . .$.$] ; /Све новаца што сам имао$ изгубио сам./ - Па ? [*uта ћеш сада да радиш?=Ø...]; /... ја сам му се јуче први пут јавио./ — И? — [*Је ли му драго било?=Ø...];

- именске речи у њиховим деклинационим облицима ${ }^{14}$ : (а) именице: Пожар! [*пожар је плануо / склоните се / ... =Ø...]; /Лице му постаде модро./ И о ч и [*му постадоше модре ... $=\varnothing . .$.$] ; /У$ питању су принципи./ Основни принциии. Срж. Морал. Нови човек. $\left[{ }^{*}\right.$ су у у питағу... =Ø...]; /Џуџа је он./ Само лисаи [*с тим што је лисаи, тј. лукав $=\varnothing . ..] ; /$ О с л у ш н у н а п ето./ Нико. [*се не појави= $\varnothing \ldots .$.

\footnotetext{
${ }^{14}$ Граматичар их означава термином искази, образлажући их: „Овакве су непотпуне реченице, значи, реченице по садржини, али не и по синтаксичком односу. У свакоме се случају њима нешто исказује, и оне се с правом зову искази (Стевановић 1973: 100-101).
} 
И без навођења других комбинација, на пример тзв. акузативних исказа, номинативних исказа, императивно-подстицајних исказа, у којима се јављају и партикуле, као и других чији се назив изводи из облика речи - ова традиционална граматика наводи и (врло детаљно) тумачи (на стр. 95119) овакве процесе у језику. Процесе у којима се као њихова основа налази контекст (вербални/графички - стварни, објективни, ситуациони), од кога полази дискурс анализа/текстлингвистика и иде у правцу граматике. Треба нагласити да ову законитост у дискурсу, коју овде формулишемо спекулативним методом, у савременој лингвистици потврђују и егзактне психолингвистичке анализе, добијене лабораторијским мерењем брзине говорникове парцелације реченице ${ }^{15}$.

Она је испитивана и код говорника за које је дати језик матерњи (овде енглески), и код говорника који су учили тај језик и са циљем да се истражи колико је успешно учење лексике страног језика код ових других. Притом, испитивана је са аспекта „односа између асоцијације речи и развоја [периепџије - допунио Сл. Ст.] лексике" - што је битно, како наглашава Ру - за "language acquisition studies, since they can provide accounts of the formal (grammatical and lexical) relations between words, the individual's internal (psycholinguistic) knowledge, as well as sociolinguistic domains (Ру 2013: 80-82).

То је свакако разлика у односу на граматику која иде од граматичких структура ка било објективном, било вербалном контексту. У томе је и традиционална граматика на страни Н. Чомског, чији смо приступ навели горе (у т. 5) и окарактерисали га цитатом (поново га наводимо) у којем се види да он ,уводи [и ставља на примарно место - допунио Сл. Ст.] елемент човекове урођене способности да поседује у својој свести „универзалну граматику (,universal grammar”), која ће обезбедити његово будуће прихватање граматичког знања" (Чомски 2006: 76-77).

8. То можемо видети из многих радова о говору („speech” одн. „inner speech" у дискурсу те литературе). Као што то видимо, нпр., у расправи Ф. Пулвермилера, Syntax as a reflex: Neurophysiological evidence for early automaticity (в. Пулвермилер 2008: 251). У њој налазимо констатацију (коју он узима од других лингвиста у томе домену) „да је главна идеја, преузета из психолингвистичких теорија - да ће уведене (у говор - прим. Сл. Ст.) лексичке јединице једновремено активирати низ могућих следећих елемената тога ланца и понудити њихове граматичке представе. Притом, последица би била да ће уведене лексичке јединице тежити избору између њих путем увођења наредне лексичке јединице што би онда довело до избора из њих потврђивањем подскупа (идеално једног) од могућих (парцелисаних) делова (реченице - допунио Сл. Ст.)". ${ }^{16}$

15 "Linguistic research has traditionally made use of word association tests in order to gain some insight as to how the mental lexicon expands during language development" (Py 2013: 80).

${ }_{16}$ "A main idea adopted from psycholinguistic theories is that incoming lexical units would simultaneously activate a range of possible successor string elements and candidate grammatical representations; subsequently incoming lexical units would then lead to a selection from these by ratifying a subset (ideally one) of the possible parses (Altmann \& Steedman, 1988; Steedman, 2000; Vosse \& Kempen, 2000). A given word or constituent would accordingly prime a range of possible future con- 
Изводећи, дакле, закључак о односу мисли и говора, који смо означили формулом говор унутрашњи : говор исказани, можемо рећи да та способност човеку у његовом унутрашњем говору (,inner speech”) омогућује асоцирање појмова који диригују говорниковим избором лексеме (са њеним значењима), као и морфосинтаксичком формом у којој ће се дата реч појавити у његовом исказу (вербалном или графичком). И, наравно обратним смером: исказан (речима) појам индукује у говорниковом унутрашњем говору лексему која је у директној колокацији са њеним значењем (в. т. 3). Као и све у говорниковом остваривању говора - цео овај процес је високо аутоматизован. Овај закључак о аутоматизованом процесу у лингвистичким наукама је и егзактно испитиван (средствима дигиталне технологије), па и потврђиван у психолингвистичкој грани опште лингвистике.

\section{ИЗВОР ГРАЪЕ}

М. Стевановић, Савремени српскохрватски језик - Граматички системи и књижевнојезичка норма, I-II, (I том: 1968, II том: 1973), Београд, Научно дело, 1974.

\section{ЛИТЕРАТУРА}

Белић 1998: А. Белић, Општа лингвистика, Изабрана дела, 1, Београд: Завод за уџбенике и наставна средства.

Белић 2000: А. Белић, О значају језичког осећања за вршене синхроничке језичке анализе, Изабрана дела, 13, Београд: Завод за уџбенике и наставна средства.

Вајли 2006: Norbert Wiley, Inner Speech as a Language: A Saussurean Inquiry, Journal for the Theory of Social Behaviour 36:3 (2006), pp. 319-421, Hoboken, New Jersey, Blackwell Publishing Ltd. [cdclv.unlv.edu/pragmatism/wiley_speech.pdf]

Виготски 1934: L. S. Vigotsky, Thinking and Speech, Vygotsky, L. S. (1987). Thinking Speech. In R. W. Rieber, \& A. S. Carton (Eds.), The Collected Works of L. S. Vygotsky (Vol. 1), Problems of General Psychology (pp. 39-285), New York: Plenum Press. (Original Work Published 1934) [Scientific Research An Academic Publisher - https://www.marxists.org/archive/ vygotsky/works/words/Thinking-and-Speech.pdf - preuzeto 30.11.2018]

Оксфорд 2018: Oxford Collocation Dictionary of English. [https://www.freecollocation.com/]

texts through the grammar network, so that the neuronal assemblies of possible successor words are pre-activated through so-called sequence detectors, discrete neuronal assemblies connecting classes of circuits for lexical items." (Пулвермилер 2008: 251). 
Половина 1999: V. Polovina, Semantika i tekstlingvistika, Beograd: Čigoja štampa. Пулвермилер 2008: F. Pulvermuller, Syntax as a reflex: Neurophysiological evidence for Early automaticity, 2008, (Edit. S.L. Small) Brain and Language 104, pp. 244-253. [webilc.ilc.cnr.it/.../PulvermullerShtyrovHastingCarlyon2008BRL_SyntaxReflex.pdf]

Радовановић 1990: M. Radovanović, Spisi iz sintakse i semantike, Sremski Karlovci - Novi Sad: Knjižarnica Z. Stojanovića.

Ристић 2000: С. Ристић, Vesna Polovina: Semantika i tekstlingvistika [prikaz], Lingvističke.aktuelnosti.1-1.pdf(1.265Mb), Beograd, 1999, 9-19. [dais.sanu. ac.rs/bitstream/handle/123456789/.../lingvisticke.aktuelnosti.1-1.pdf?...1... dais.sanu.ac.rs/bitstream/handle/123456789/.../lingvisticke.aktuelnosti.1-3. PDF?...1... (http://main.amu.edu.pl/ sipkadan/la.htm). ]

Py 2013: P. W. Roux, Words in the Mind: Exploring the relationship between word association and lexical development, Polyglossia, Volume 24, March 2013, Asia Pacific University, Jumonjibaru, Beppu, Japan, pp. 80-91. [https://core. ac.uk/download/pdf/60540582.pdf ]

Tерон 2018: K. Theron, Speech and Language Processing: Models, Theories and the Influence of Contextual Factors, University of Pretoria, 2018, 1-59. [https://repository.up.ac.za/bitstream/handle/2263/27081/02chapter2.pdf?sequence $=3$ ]

Христудолидес 2016: G. Christodoulides, Effects of Cognitive Load on Speech Production and Perception, $\mathrm{PhD}$ Thesis, Université catholique de Louvain, September 2016 [www.afcp-parole.org/doc/theses/these_GC16.pdf]

Чомски 2006: N. Chomsky, Language and Mind (Third Edition), (2006), Cambridge - NewYork: Cambridge University Press [www.ugr.es/ fmanjon/Language $\% 20$ and $\% 20$ Mind.pdf - preuzeto - 22. 10. 2018]

\section{Slavko Stanojčić}

\section{FORMULA "OVERT SPEECH : INNER SPEECH” AND DEFINITIONS OF INCOMPLETE} SENTENCES IN TRADITIONAL GRAMMAR

Summary

Paper brings results of author's research of a representative for $20^{\text {th }}$ Century grammar of Serbian, in its syntax segment aimed to definitions and analysis of so-called uncomplete sentences. Target of research is stating if eventual presence of analytic formula overt speech : inner speech exists in them. By speculative method, which starts from theoretical discussions (of a number of other researchers), authors concludes that formulas of this type are present in the grammar only as an implicated category. By author's opinion, it is mostly based on intuition and spontaneous associations connected with Serbian linguist A. Belić's teachings on connection of meaning and language units in all different levels of the language in communication. By so posted research of pragmatics, by means of inductive concluding, according to author these researches, by an inductive way, could result in generalization of a theoretical nature.

Key words: formula, overt speech : inner speech, traditional grammar, instrumentarium psycho-/ cogno-/socio/-textlinguistics, Stevanović, Chomsky, Radovanović, Vigotsky, Wiley, Theron. 